\title{
Kielteiset tunteet kulttuurienvälisten vuorovaikutustaitojen oppimisessa
}

\section{Miten niihin tulisi suhtautua?}

\author{
$+y$ \\ Kielteisten tunteiden kokeminen on hyödyksi \\ kulttuurienvälisten vuorovaikutustaitojen oppimiselle, \\ jos tunteet vain tunnistetaan ja otetaan huomioon \\ työyhteisökoulutuksissa. Kouluttajan on tuettava \\ tunteiden käsittelemistä ja hyödynnettävä \\ osallistujien kokemuksia.
}

TYÖELÄMÄN KULTTUURINEN monimuotoistuminen ja työn luonteen muuttuminen yhä vuorovaikutteisemmaksi on luonut tarpeen koulutuksille, joissa pohditaan kulttuurisesti erilaisten ihmisten johtamista ja kehitetään valmiuksia työskennellä eritaustaisten työtoverien ja asiakkaiden kanssa. Ammattitaitoa täydentävissä koulutuksissa tai eri alojen koulutusohjelmiin sisällytetyissä kursseissa opetellaan, kuinka ihmisten välinen erilaisuus kannattaa ottaa huomioon johtamisessa, tiimityössä ja vuorovaikutuksessa.
Moninaisuutta käsittelevät kurssit ovat usein osa johtajuusopintoja, kun taas kulttuurienvälistä vuorovaikutusta opetetaan useissa oppilaitoksissa ja korkeakouluissa, joista valmistuu ammattilaisia sairaanhoitajista insinööreihin ja kieltenopettajiin.

Moninaisuuskurssien ja kulttuurienvälisen vuorovaikutuskoulutusten osallistujien on esitetty kokevan koulutuksissa usein kielteisiä tunteita. Esimerkiksi Diana Bilimoria ym. $(2010,856)$ kirjoittavat, kuinka monet heidän ohjaamansa moninaisuuskurssin osanottajat tunsivat, että heidät nähtiin stereotyyp- 
pisesti, heitä vastaan hyökättiin, heitä ei kunnioitettu ja heidät hiljennettiin. Duncan Spelman (2010) ja Eric Patton (2010) selittävät, miksi sekä marginalisoituihin että dominoiviin yhteiskunnallisiin ryhmiin kuuluvat ihmiset voivat tuntea itsensä uhatuiksi oppimistilanteissa, joissa käsitellään eri kulttuurisiin ryhmiin kuuluvien ihmisten välisiä suhteita. Itsekin olen kulttuurienvälisiä vuorovaikutustaitoja opettaessani huomannut, että erilaisuus ja eri ryhmien väliset suhteet ovat aihe, jonka käsittelyssä tunteisiin on kiinnitettävä erityistä huomiota.

Erilaisuutta ja erilaisia vuorovaikutustapoja käsittelevissä koulutuksissa koettuihin tunteisiin vaikuttaa sekin, että niissä käytettävät metodit perustuvat usein kriittiseen reflektioon ja kriittiseen itsereflektioon. Oppijaa ohjataan arvioimaan, pitävätkö hänen oletuksensa esimerkiksi työnteosta, työkavereista, asiakkaista tai sopivaa käyttäytymisestä määrittävistä normeista paikkansa, mihin ne perustuvat ja mitä seurauksia niillä on. Lisäksi häntä ohjataan arvioimaan omaa näkökulmaansa sekä tapaansa havaita, olettaa ja toimia. (Gray 2007, 497-498). Erityisesti oman statuksen ja sen vaikutusten kriittinen tarkastelu herättää usein epämiellyttäviä tunteita, kuten vihaisuutta, ahdistusta, epävarmuutta ja pelkoa, sekä vahvoja reaktioita, kuten puolustautumista, anteeksi pyytelemistä ja vetäytymistä (Clarke 2009, 127; Mezirow 2000, 6; Spelman 2010, 884).

Pohdin, miten kulttuurienvälisen vuorovaikutuksen koulutuksissa herääviin kielteisiin tunteisiin tulisi suhtautua. Ovatko kielteiset tunteet vain oppimisen este, mikä tarkoittaisi, että niitä tulisi yrittää ehkäistä, vai voidaanko niitä käyttää oppimisessa hyväksi? Millainen merkitys kielteisillä tunteilla on erityisesti kulttuurienvälisten vuorovaikutustaitojen oppimisessa? Lisäksi peilaan ajatuksiani omiin kokemuksiini, erityisesti toimintaani kulttuurienvälisen vuorovaikutuksen kouluttajana Kulttuurien välisen työn valmiuksien kehittäminen sosiaali- ja terveydenhuollon työssä -hankkeessa, joka tunnetaan nimellä MULTI-TRAIN. Suomen Akatemian rahoittamassa ja Tampereen ja ItäSuomen yliopiston vuosina 2013-2017 toimeenpanemassa tutkimushankkeessa kehitettiin sosiaali- ja terveydenhuollon alan työyhteisöjä kohti yhä sujuvampaa kulttuurienvälistä arkea (http:// www.uta.fi/edu/tutkimus/tutkimushankkeet/ multitrain/index.html).

Viittaan tunteilla emotionaalisiin tiloihin, joita ihmiset luettelevat, kun heiltä kysytään, "mitä tunnet". Kuten Stephen Fineman $(2004,731)$ huomauttaa, tunteet voivat olla vaihtelevia, epämääräisiä, toisiinsa sekoittuvia ja ristiriitaisia ja siten vaikeasti ilmaistavissa. Siksi ihmiset saattavat kysyttäessä luetella useita ja jopa keskenään ristiriitaisia tunteita.

Kielteisillä tunteilla viittaan tunteisiin, joita on epämiellyttävä kokea. En oleta tunteiden olevan pelkkiä ihmisen sisäisiä tapahtumia vaan Barbara Simpsonia ja Nick Marshallia (2010, 353-357) seuraten ainakin osittain sosiaalisesti rakentuneita ja kulttuurispesifejä ilmiöitä, jotka nousevat pikemminkin meneillään olevasta tapahtumien sarjasta kuin yksilöstä.

\section{KULTTUURIENVÄLISET VUOROVAIKUTUSTAIDOT OVAT YHTEISTYÖN VÄLINE}

Termillä 'kulttuurienvälisyys' viitataan vuorovaikutustilanteeseen, jossa ihmisten väliset eroavaisuudet ovat riittävän merkittäviä luodakseen erilaisia tulkintoja ja odotuksia siitä, millainen toiminta ja vuorovaikutus tilanteessa on sopivaa (Spitzberg \& Cupach 1993, 58). Ihmisen ei oleteta edustavan yhtä kulttuuria, vaan hänet nähdään monien kulttuuristen vaikutteiden muovailemana olentona, joka pystyy reflektoimaan ajatteluaan, toimintaansa ja vaikuttimiaan niiden taustalla sekä ainakin joiltain osin valitsemaan, mitkä kulttuuriset vaikutteet ovat hänelle merkityksellisiä.

Kulttuurienväliset vuorovaikutustaidot jaetaan yleensä asenteisiin ja tunteisiin, tietoisuuteen ja tietoon sekä toimintaan ja käyttäytymiseen (Martin \& Nakayama 2015, 17-18). Koulutuksissa pyritään edistämään asenteiden ja tunteiden, kuten kunnioituksen, avomielisyyden ja empatian, syntymistä. Lisäksi luodaan ymmärrystä siitä, kuinka kunkin oma kulttuuritausta vaikuttaa päättelyyn, tuntemiseen ja käyttäytymiseen sekä tuetaan ennakkoluulojen ja eriarvoistavien toimintatapojen tunnistamista ja yhteistyötä helpottavia käytännön taitoja. 
Kielteisten TUNTEIdEN

KOKEMINEN VOI

\section{ANTAA IHMISELLE}

\section{MAHDOLLISUUDEN TUTKIA}

\section{OMIA V ÄLTTELEMISEN}

\section{JA PUOLUSTAUTUMISEN}

\author{
MEKANISMEJAAN JO
}

KOULUTUKSESSA.

Omissa koulutuksissani painotan, että kulttuurienvälisissä tilanteissa on tarpeen osata tiedostaa ja tuoda esiin tilannekohtaista ja kulttuurisidonnaista tietoa sekä rakentaa yhdessä toisten kanssa käsitystä siitä, millainen toiminta kyseisessä tilanteessa on toivottavaa. Painotus johtuu siitä, että koulutan usein työyhteisöissä. Vaikka työyhteisöissä on työskentelyä ja vuorovaikuttamista sääteleviä normeja, ne eivät ole riittävän kattavia kertoakseen tilanne tilanteelta, kuinka työntekijöiden odotetaan keskenään ja asiakkaiden kanssa toimivan. Työntekijöiden on siis tarvittaessa osattava tiedostaa, että tilanteessa on erilaisia toimintamahdollisuuksia sekä neuvotella, millaisten toiminta- ja vuorovaikutustapojen varassa yhteistyö parhaiten onnistuu.

Kun opetustilanteessa tarkastelemme, millaisia oletuksia eri osapuolilla on tilanteen etenemisestä, mahdollista rooleista ja sopivasta käyttäytymisestä, teen kouluttajana kysymyksiä, jotka vievät pohdintaa kohti kriittistä reflektiota ja itsereflektiota. Tämä johtaa yleensä ajatusten, tunteiden, toiminnan ja motivaatioiden syvälliseen tarkasteluun, minkä myötä osallistujat tulevat yhä tietoisemmiksi ajatteluprosesseistaan. He toisin sanoen kehittävät metakognitiivisia taitojaan, joiden on todettu olevan oppimiselle ja vuorovaikuttamiselle merkittäviä (Bilimoria ym. 2010, 864; Hakkarainen ym. 2004, 238-239).

Parhaimmillaan kriittinen itsereflektio johtaa yhä yhteiskunnallisempaan näkemykseen ja sitä myötä valtasuhteiden merkityksen, omien etuoike- uksien sekä syrjivien näkemysten ja toimintatapojen oivaltamiseen (Collier 2015, 10). Juuri tähän suuntaan moninaisuuskursseja ja vuorovaikutuskoulutuksia tulisi kriittisten tutkijoiden mukaan viedä: erilaisuuden tarkastelun sijaan keskiöön tulisi asettaa eriarvoisuus ja sen tuottaminen (Gorski 2008) - eli juuri ne asiat, jotka herättävät yleensä eniten kielteisiä tunteita.

\section{KIELTEISISTÄ TUNTEISTA VOI OLLA HYÖTYÄ OPPIMISESSA}

Koska oppiminen on tutkimisen ja uudelleen rakentamisen prosessi, jossa ihmisen käsitykset ja käyttäytyminen muuttuvat ainakin jonkin verran ennalta-arvaamattomaan suuntaan, ei ole yllättävää, että oppiminen aiheuttaa toisinaan ahdistusta. On esitetty, että ihminen saattaa kokea ahdistusta, kun hänen tapansa tulkita tapahtumia on riittämätön (Simpson \& Marshall 2010, 354-361.) Kulttuurienvälisissä kohtaamisissa on ilmeistä, että ihmiset eivät tulkitse tilannetta ja toimi siinä samalla tavalla - juuri siksihän kohtaaminen määritellään kulttuurienväliseksi. Sen vuoksi on tärkeää, että erilaisia tapoja käsittää tilanne tuodaan koulutuksissa esiin tarkoituksellisesti. Oppiminen voidaan tällöin ymmärtää Viktor J. Friedmania ja Ariane B. Antalia $(2005,70)$ seuraten omien henkilökohtaisten ajattelu-, tunne- ja käyttäytymismallien tarkasteluksi ja kyseenalaistamiseksi sekä sitä kautta saavutettavaksi kyvyksi tutkia yhdessä toisten kanssa ajattelun, tuntemisen ja käyttäytymisen taustalla vaikuttavia oletuksia ja testata erilaisia ajattelun ja toiminnan tapoja.

Kriittisen reflektioon ja itsereflektioon perustuvat menetelmät auttavat tässä prosessissa. Esimerkiksi Ann Cunliffe $(2004,407)$ määrittelee kriittisen itsereflektion prosessiksi, jossa ihminen suostuu huomaamaan, että ne oletukset, diskurssit ja käytännöt, joilla hän yleensä todellisuutta kuvaa, eivät välttämättä ole totta. Kulttuurienvälisten vuorovaikutustaitojen oppiminen voidaankin mieltää Jack Mezirowta (2000, 6-7) seuraten uudistavaksi oppimiseksi, jossa pyritään ylittämään omat itsestään selvät ajattelu- ja toimintatottumukset. 
Aiempien tutkimusten perusteella vaikuttaa siltä, että tunteet ovat oppimisen kannalta olennaisia silloinkin, kun niitä ei varta vasten kutsuta esiin houkuttelemalla ihmisiä kyseenalaistamaan käsityksiään, identiteettiään ja toimintaansa. Erityisesti myönteisten tunteiden on todettu edistävän oppimista (Clarke 2009, 137; Hakkarainen ym. 2004, 210; Varila 1999, 42). Kielteiset tunteet saattavat puolestaan saada ihmiset puolustautumaan, mikä voi ehkäistä oppimista ja estää näkökulmien vaihtamista (Aarnio 2010, 161).

On myös esitetty, että kielteinen tunnetila voi saada ihmisen reflektoimaan myönteistä tunnetilaa enemmän (Varila 1999, 91), ja joidenkin tutkimusten mukaan kielteisillä tunteilla, kuten suuttumisella ja ahdistuksella, saattaa olla myönteisiä tunteita intensiivisempiä ja pitkäkestoisempia vaikutuksia esimerkiksi muistiin ja informaation käsittelyyn. Lisäksi kielteisiksi mielletyt tapahtumat saattavat saada ihmiset oppimaan paremmin uusia käyttäytymismalleja. (Clarke 2009, 137.) Riitta-Liisa Arpiainen ym. $(2013,333)$ ehdottavatkin, että kielteisetkin tunteet voivat hyödyttää oppimista ainakin niin kauan kuin ne ovat tasapainossa myönteisten tunteiden kanssa. Ristiriitoja, konflikteja ja anomalioita voidaan käyttää hyödyksi säätelemällä oppimisprosessia sopivalla tavalla.

Kouluttajana olen huomannut, että koulutustilanteissa osallistujat käyvät usein läpi samoja tunteita kuin kulttuurienvälisissä kohtaamisissa. He ovat maininneet tuntevansa kohtaamisissa muun muassa ärsyyntymisen, turhautumisen, kuormittumisen, suuttumisen, nolouden, epäoikeudenmukaisuuden, loukkaantumisen ja epävarmuuden tunteita. Kun olemme käsitelleet yhdessä kielteisiä tunteita herättäneitä tapahtumia, osallistujat ovat raportoineet tuntevansa samanlaisia tunteita kuin ollessaan tapahtumien keskellä. Sen jälkeen, kun olemme käsitelleet näitä kohtaamisia, kyseenalaistaneet niissä käytettyjä päättely- ja toimintatapoja sekä kehitelleet uusia tapoja ymmärtää tilanne ja toimia siinä, he ovat kertoneet tunteidensa muuttuneen aiempaa myönteisemmiksi.

Esitänkin, että ainakaan kulttuurienvälisen vuorovaikutuksen koulutuksissa koettuja kielteisiä tun- teita ei tulisi pitää vain oppimisen esteinä, vaan ne saattavat hyödyttää oppimista monella tavalla. Ensinnäkin kielteiset tunteet ovat tavallisia kulttuurienvälisissä kohtaamisissa, ja siksi on hyvä oppia kohtamaan niitä jo koulutuksessa. Toiseksi ne saattavat motivoida jatkamaan oppimista, sillä oppimisen voi odottaa helpottavan oloa.

Kolmanneksi kielteisten tunteiden kokeminen voi antaa ihmiselle mahdollisuuden tutkia omia välttelemisen ja puolustautumisen mekanismejaan jo koulutuksessa. Tarkkaillessaan kielteisten tunteiden nousemista ja niiden motivoimaa toimintaansa ihminen saattaa ymmärtää yhä paremmin, kuinka tunteet vaikuttavat hänen tapoihinsa olla vuorovaikutuksessa (Aarnio 2010, 161).

Neljänneksi tunteet voivat kertoa jotain merkittävää tilanteesta (Varila 1999, 95) ja osallistujan identiteetistä ja siten avata mahdollisuuden keskustella vaikeista teemoista, kuten vallasta ja valtasuhteista, alistamisesta, statuksesta, etuoikeuksista ja stereotyypeistä (Warren 2008). Lisäksi niiden ilmeneminen kertoo syvällisen oppimisprosessin olevan käynnissä ja ohjaa kriittisen reflektion prosesseissa. Kielteisten tunteiden kokeminen antaa myös tilaisuuden harjoittaa tunteiden säätelemisen taitoa, minkä on todettu auttavan oppimisessa ja vuorovaikutuksessa. (Clarke 2009, 131-139.)

\section{TUNTEIDEN ILMENEMISTÄ ON HYVÄ ENNAKOIDA}

Jotta kielteisistä tunteista olisi hyötyä oppimisessa, on tiedettävä, kuinka oppimista voidaan helpottaa tilanteissa, joissa tunteita ilmenee. Riitta-Liisa Arpiainen ym. $(2013,343)$ ehdottavat, että kielteisten tunteiden ja ongelmien sivuuttaminen voi johtaa niiden kasautumiseen ja sitä myötä huonoihin oppimiskokemuksiin. Kun tarjotaan sopivanlaista tukea sopivaan aikaan, kielteiset tunteet voidaan kuitenkin muuttaa myönteisiksi oppimiskokemuksiksi.

Kokemukseni mukaan tukeminen kannattaa aloittaa jo ennen kielteisten tunteiden ilmenemistä avaamalla hyvin koulutuksen tavoitteet ja metodit sekä kertomalla, että koulutuksessa tyypillisesti herää monenlaisia tunteita, myös kielteisiä. Erityisesti kriittisen reflektion ja itsereflektion käyttämistä 
koulutuksessa on hyvä perustella, jotta osallistujat ovat valmiita jatkamaan oppimista silloinkin, kun se haastaa heidän käsityksensä ja identiteettinsä. Saattaa olla myös hyödyllistä miettiä yhdessä, miten kielteisiä tunteita voi helpottaa ja säädellä.

Usein jo tunteiden ääneen toteaminen helpottaa koulutukseen osallistuvan oloa ja antaa mahdollisuuden saada vertaistukea ryhmästä. Kannustavan ja turvallisen oppimisympäristön merkitystä ei voi yliarvioida. Kouluttajan kannattaa pyrkiä luomaan ilmapiiri, jossa on turvallista tarkastella ja kyseenalaistaa omia ja muiden näkemyksiä sekä niiden perusteita, tuntea tunteita, kertoa niistä ja oppia säätelemään niitä. Olennaista on, että ilmapiiri sallii ja suorastaan rohkaisee epäonnistumaan ja näkemään epäonnistumiset oppimismahdollisuuksina. (Arpiainen ym 2013, 344; Bilimoria ym. 2010, 865-866.)

Kulttuurienvälisen vuorovaikutuksen koulutuksessa omien ja toisten näkemysten ja niiden perusteiden tutkiminen on läsnä sekä sisällöissä että metodeissa. Osallistujia rohkaistaan suhtautumaan vuorovaikutustilanteiden epäonnistumisiin myönteisesti, sillä ne paljastavat, missä kohtaa vuorovaikutuksen osapuolten käsitykset tilanteesta ja siihen sopivasta käyttäytymisestä eivät kohtaa. Kun osallistujat tarkastelevat kielteisiä tunteitaan ja niiden merkitystä, he samalla tutkivat niihin yhteydessä olevia ajatuksia, minkä on todettu helpottavan kielteisten tunteiden hyödyntämistä oppimisessa (Hakkarainen ym. 2004, 210).

Kielteisiä tunteita herättävien teemojen ja tilanteiden käsittely saattaa olla kouluttajalle vaativaa. Hänen tulisi kyetä tarkkailemaan opetustilanteen emotionaalista ilmapiiriä, huomioimaan omia ja muiden tunteita ja puuttumaan ongelmiin, jos niitä ilmenee. Kouluttajan pitäisi osata tarkastella itseään ja omien oletustensa perusteita sekä säädellä omia reagointitapojaan ja samalla ohjata muita tekemään niin (Aarnio 2010, 164). Toisin sanoen kouluttajan tulee osallistua kriittisen reflektion prosesseihin samalla kun hän strukturoi ja mallintaa niitä (Spelman 2010, 889).

Itse pyrin ilmentämään tutkivaa asennettani ja haluani kuunnella esimerkiksi puhetavallani: sen sijaan, että kertoisin valmiiksi ajateltuja asioita, kuvailen päättelyprosessejani, kyselen osallistujien näkemyksiä niistä ja ilmaisen kielenkäytölläni epävarmuutta. Puhun omasta kulttuurisesta identiteetistäni ja tilanteista, joissa se on ollut uhattuna. Paljastan paikkaansa pitämättömiä oletuksiani ja tutkin ajatteluani ja tunteitani yhdessä muiden kanssa.

Monia oppimismetodeja voidaan käyttää niin, että ne johtavat kriittiseen reflektioon ja itsereflektioon. Yleisesti käytettyjä metodeja ovat muun muassa tarinoiden kertominen, tekstien ja kuvien analysointi, reflektiiviset keskustelut, kriittisten tapausten analysointi, tahattomien päätelmien testit ja reflektiivisen oppimispäiväkirjan kirjoittaminen. Metodia olennaisempaa on, käytetäänkö sitä niin, että koulutuksen osallistujat voivat pohtia omia tapojaan havaita, tulkita, tuntea, päätellä ja käyttäytyä. Kouluttajan kannattaa käyttää metodeja, jotka saavat osallistujat tarkastelemaan tilanteita muiden kuin itsensä näkökulmasta. Heitä voi muistuttaa, että oppiminen riippuu kunkin yrityksestä ymmärtää toisten ajatuksia ja tunteita (Warren 2008), tai vaihtoehtoisesti, että haluttomuus tai kyvyttömyys nähdä tilanteita toisten näkökulmasta ehkäisee oppimista (Simpson \& Marshall 2010, 356).

\section{TUNTEET KERTOVAT TYÖYHTEISÖSTÄ}

Erityisesti työyhteisöissä on hyödyllistä ohjata koulutettavia miettimään, mitä vuorovaikutuksessa heräävät tunteet kertovat työtilanteista, -rooleista ja -kulttuureista. Kun tunteet ovat ainakin osittain sosiaalisesti rakentuneita, tuntemisessa on merkittävää, kuinka tuntemuksia ja ajatuksia luokitellaan. Se taas riippuu siitä sosiaalisesta ja kulttuurisesta kontekstista, joka tarjoaa tunteiden säännöt ja sanaston. Näin tunteet eivät ole ihmisissä itsessään vaan ikään kuin ihmisten välillä: ne on tuotettu niissä neuvotteluissa, joissa merkitysjärjestelmiä eli kulttuureita luodaan. (Fineman 2000, 2.) Siten tilanteiden lukeminen jollakin tietyllä tavalla mahdollistaa tietynlaisen tunteen heräämisen ja siihen sidoksissa olevan reaktion (Simpson \& Marshall 2010, 354). Onkin mielekästä kysyä, miksi turhautuneisuus, vihaisuus ja kuormittuneisuus esiintyvät niin usein kulttuurienvälisissä kohtaamisissa työpaikoilla. 
Jos kuormittumisen, ärsyyntymisen, turhautuneisuuden ja kohtuuttomuuden tunteet toistuvasti heräävät, tilanteita hallitsevat käytännöt ja oletukset eivät välttämättä anna arvoa ihmisten väliselle vuorovaikutukselle tai erilaisille kokemuksille ja näkemyksille.

Kulttuurien välisen vuorovaikutuksen koulutuksissa kannattaa tarkastella, mahdollistavatko työyhteisön toimintatavat ja työkäytännöt riittävän vuorovaikutuksen vai puuttuuko siihen tilaisuuksia. Entä olettavatko työntekijät, että vuorovaikutukseen käytetty aika estää heitä työskentelemästä tehokkaasti ja ahkerasti? Minkä pitäisi muuttua, jotta vuorovaikutuksessa kulutetun ajan ei koettaisi verottavan työntekoa vaan olevan olennainen osa työskentelyä? Lisäksi voi tarkastella, millaisia pätevien työntekijöiden oletetaan työyhteisössä olevan. Oletetaanko heidän jakavan samanlaisen sosiokulttuurisen taustan, jota vasten he ymmärtävät asioita samalla tavalla joutumatta keskustelemaan työskentelyn päämääristä ja tavoista?

Kriittinen reflektio ja itsereflektio saattavat paljastaa, kuinka ihmisen oletukset ja odotukset ovat yhteydessä työpaikan kulttuuriin ja historiaan. Sen myötä voi syntyä uudenlaista ymmärrystä siitä sosiaalisesta, poliittisesta ja taloudellisesta kontekstista, jossa tietynlainen työkulttuuri on syntynyt. Tämä voi avata uusia mahdollisuuksia ja keinoja kehittää toiminta- tapoja ja koko työyhteisöä niin, että jokainen työntekijä kokee tulevansa arvostetuksi.

Koska kriittisen reflektion ja itsereflektion prosessit eivät pysähdy henkilökohtaiselle tasolle tarkastelemaan kunkin omia ajattelu- ja toimintatapoja vaan laajenevat koskemaan uskomuksia, ideologioita, arvoja ja käytäntöjä sekä niiden mahdollistamia valtasuhteita, etuoikeuksia ja syrjintää, kriittiseen reflektioon ja itsereflektioon pohjautuvat metodit voivat herättää kielteisiä tunteita. Syrjivien asenteiden ja rakenteiden tunnistaminen on osa kulttuurienvälisiä vuorovaikutustaitoja, eikä niiden käsittelemistä pitäisi välttää kielteisten tunteiden heräämisen pelossa. Sen sijaan, että kielteisistä tunteista ja niitä herättävistä aiheista vaietaan koulutuksessa tai ne sivuutetaan kokonaan, osallistujia kannattaa ohjata tiedostamaan tunteensa ja sen, millaiseen näkökulmaan ne liittyvät.

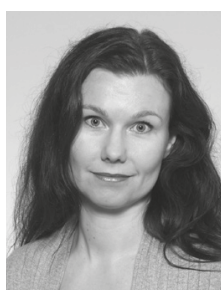

KATJA KEISALA, tutkijatohtori, YTT Kasvatustieteiden tiedekunta Tampereen yliopisto 
Aarnio, H. (2010). Oppimisen ohjaaminen. Teoksessa Helkorpi, S., Aarnio, H. \& Majuri, M. (toim.) Ammattipedagogiikkaa uuteen oppimiskulttuuriin. Hämeenlinna: Hämeen ammattikorkeakoulu.

Arpiainen, R-L., Lackéus, M., Täks, M. \& Tynjälä, P. (2013). The Sources and Dynamics of Emotions in Entrepreneurship Education Learning Process. TRAMES, 17(67/62)(4), 331-346.

Bilimoria, D., O’Neil, D. A., Hopkins, M. M. \& Murphy, V. (2010). Gender in the management education classroom: a collaborative learning journey. Journal of Management Education 34(6), 848-873.

Clarke, N. (2009). Emotional intelligence and learning in teams. Journal of Workplace Learning 22(3), 125-145.

Collier, M. J. (2015). Intercultural communication competence: Continuing challenges and critical directions. International Journal of Intercultural Relations 48, 9-11.

Cunliffe, A. L. (2004). On becoming a critically reflexive practitioner. Journal of Management Education 28(4), 407-426.

Fineman, S. (2000). Emotional arenas revisited. Teoksessa Fineman, S. (toim.) Emotion in Organizations. London: Sage, 1-24.

Fineman, S. (2004). Getting the measure of emotion and the cautionary tale of emotional intelligence. Human Relations 57(6), 719-740.

Friedman, V. J. \& Antal, A. B. (2005). Negotiating reality: A theory of action approach to intercultural competencies. Management Learning 36(1), 69-86.

Gorski, P. C. (2008). Good intentions are not enough: a decolonizing intercultural education. Intercultural Education 19(6), 515-525.

Gray, D. E. (2007). Facilitating management learning. Developing critical reflection through reflective tools. Management Learning 38(5), 495-517.
Hakkarainen, K., Lonka, K. \& Lipponen, L. (2004). Tutkiva oppiminen. Järki, tunteet ja kulttuuri oppimisen sytyttäjinä. Helsinki: WSOY.

Martin, J. N. \& Nakayama, T. K. (2015). Reconsidering intercultural (communication) competence in the workplace: a dialectical approach. Language and Intercultural Communication 15(1), 13-28.

Mezirow J. (2000). Learning to think like an adult: core concepts of transformation theory. Teoksessa Mezirow, J. \& Associates (toim.) Learning as Transformation. Critical Perspectives on a Theory in Progress. San Francisco: Jossey-Bass, 3-33.

Patton, E. (2010). When social identities collide: commentary on "gender in the management education classroom". Journal of Management Education 43(6), 874-881.

Simpson, B. \& Marshall, N. (2010). The mutuality of emotions and learning in organizations. Journal of Management Inquiry 19(4), 351-365.

Spelman, D. (2010). Recognizing the centrality of emotion in diversity courses: commentary on "gender in the management education classroom". Journal of Management Education 43(6), 882-890.

Spitzberg, B. H. \& Cupach, W. R. (1993). Interpersonal Communication Competence. London: Sage Publications.

Varila, J. (1999). Tunteet ja aikuisdidaktiikka. Tunteiden aikuisdidaktisen merkityksen teoreettinen ja empiirinen jäljitys. Kasvatustieteellisen tiedekunnan tutkimuksia. Joensuu: Joensuun yliopisto.

Warren, Lee (2008). Managing hot moments in the Classroom. Derek Center for Teaching and Learning. Harvard University. Online document. http://isites. harvard.edu/fs/html/icb.topic58474/hotmoments.html. 